\title{
A novel fluorescent turn-on probe for bisulfite based on NBD chromophore
}

\author{
PUHUI XIE*§, GUANGQIN GAO ${ }^{\S}$, WENJIE ZHANG, GUOYU YANG and QIU JIN \\ College of Sciences, Henan Agricultural University, Zhengzhou 450002, P. R. China \\ e-mail:phxie2013@163.com
}

MS received 31 December 2014; revised 2 April 2015; accepted 4 April 2015

\begin{abstract}
A novel fluorescent turn-on probe (compound 1) for bisulfite based on 7-nitrobenz-2-oxa-1,3diazole (NBD) chromophore has been developed. Its sensing behavior toward various anions was investigated by absorption and fluorescence techniques. This probe shows a selective, turn-on fluorescent response and ratiometric colorimetric response toward bisulfite in aqueous acetonitrile solutions. The possible recognition mechanism of probe $\mathbf{1}$ toward bisulfite was illustrated by MS spectra analysis and DFT calculations Probe $\mathbf{1}$ was used to determine bisulfite in real-life samples with good recoveries.
\end{abstract}

Keywords. Fluorescent probe; turn-on; NBD chromophore; bisulfite.

\section{Introduction}

Fluorescence spectroscopy has become a powerful technique for sensing and imaging trace amounts of fluorescent samples due to its simplicity, sensitivity, fast response times, as well as its application for in vivo imaging. The exploration of fluorescent probes for anions has attracted considerable attention in recent years because many biological processes involve molecular recognition of anionic species. ${ }^{1-5}$

However, due to their diverse geometries, charge distributions, sizes and high enthalpies of hydration of anions, which present an obvious obstacle to develop probes with abilities to function in aqueous media, it is very difficult to develop anion recognition systems. ${ }^{6}$ Even so, various probes for anions have been developed based on noncovalent interactions such as hydrogen bonding, ${ }^{7-11}$ electrostatic interactions ${ }^{12-17}$ or displacement reaction through coordination with metal complexes. ${ }^{18-21}$ A special chemical reaction between a receptor and target species will give a unique spectroscopic change and provide us versatile means to investigate a wide range of analytes with superior selectivity. ${ }^{22,23}$ Hydrogen bonding is an important noncovalent force often involved in the formation of supramolecular structures. In the area of photophysics, it has been generally recognized that formation of hydrogen bonds can restrict the intramolecular rotations, and rigidify the molecular structures, and help to minimize the nonradiative energy losses of the excitons

*For correspondence

$\S$ Puhui Xie and Guangqin Gao are contributed equally to this work. and maximize the probability of radiative transition, resulting in turn-on of the emission.

Bisulfite is one of the anions that has been widely used as an additive in foods, beverages and pharmaceutical products. It acts as an antimicrobial agent, enzyme inhibitor and antioxidant. ${ }^{24-29}$ However, bisulfite in certain concentrations has been associated with allergic reaction and food intolerance symptoms, such as difficulty in breathing, wheezing, hives, and gastrointestinal distress. ${ }^{30-34}$ Therefore, development of a sensitive and selective fluorescent sensor for the determination of bisulfite is of great importance for food safety and quality control, clinical and environmental applications.

In this work, we introduced pyrrole group to 7nitrobenz-2-oxa-1,3-diazole (NBD) fluorophore to construct a $\mathrm{HSO}_{3}^{-}$-selective sensor. NBD was chosen as the fluorophore because of long emission wavelength, good cell permeability and applications in chemical biology and bioanalytical studies. ${ }^{35-37}$ The pyrrole functionated NBD derivate (scheme 1) was expected to interact with $\mathrm{HSO}_{3}^{-}$through hydrogen bonding, producing a strongly fluorescent $\mathrm{HSO}_{3}^{-}$adduct of the receptor.

\section{Experimental}

\subsection{Reagents and apparatus}

Acetonitrile of spectroscopic grade and deionized water (or distilled) were used throughout the experiment as solvents. All the chemicals of analytical grade for syntheses were purchased from commercial suppliers and were used without further purification. NMR spectra 


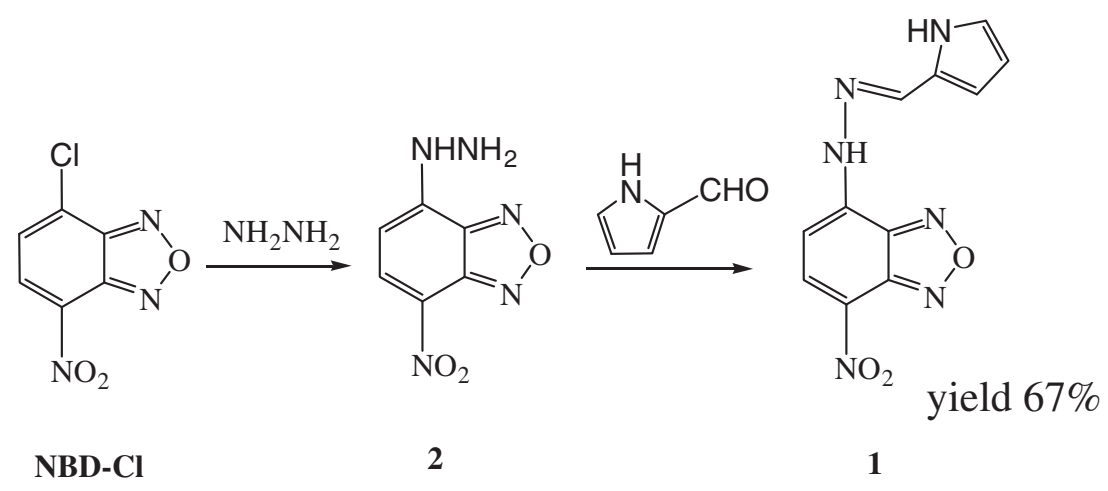

Scheme 1. General procedure for the synthesis of probe $\mathbf{1}$.

were recorded with a $400 \mathrm{MHz}$ Varian spectrometer. Electrospray ionization mass spectra (ESI-MS) were measured on a micrOTOF-Q II system. Absorption spectra were obtained on a TU1901 Ultraviolet-visible spectrophotometer. The fluorescence spectra were measured with a Cary Eclipse fluorescence spectrometer.

\subsection{Syntheses}

Compound 2 was prepared similar to the reported procedures by using NBD-Cl and hydrazine hydrate as raw materials. ${ }^{38}$ Hydrazine monohydrate $(1.5 \mathrm{~mL}, 30 \mathrm{mmol})$ in $20 \mathrm{~mL} \mathrm{CH}_{3} \mathrm{OH}$ was added in dropwise to a solution of NBD-Cl $(200 \mathrm{mg}, 1 \mathrm{mmol})$ in $20 \mathrm{~mL} \mathrm{CHCl}{ }_{3}$ The resulting solution was stirred at room temperature for $3 \mathrm{~h}$. A yellowish-brown precipitate appeared gradually. It was filtered and washed with small amount of $\mathrm{CHCl}_{3}$, then dried under vacuum at $50^{\circ} \mathrm{C}$ to get the desired product (140 mg, 84\%), which was used for the next step without further purification.

2-Pyrrole aldehyde ( $234 \mathrm{mg}, 2.5 \mathrm{mmol}$ ) was added to a solution of compound 2 (160 mg, $0.82 \mathrm{mmol})$ in $6 \mathrm{~mL}$ absolute ethanol. One drop of acetic acid was added to catalyze the reaction. The mixture was stirred at room temperature for $20 \mathrm{~h}$. The solvent was evaporated in vасио. The residue was purified by column chromatography on silica gel with ethyl acetate/hexanes $(1 / 3, \mathrm{v} / \mathrm{v})$ to afford a dark red solid of $0.13 \mathrm{~g}$ in $67 \%$ yield. ${ }^{1} \mathrm{H}$ NMR (DMSO-d 6 , $\delta$, ppm), $12.95(\mathrm{~s}, 1 \mathrm{H}), 11.79(\mathrm{~s}, 1 \mathrm{H})$, $8.59(\mathrm{~d}, J=9.2 \mathrm{~Hz}, 1 \mathrm{H}), 8.43(\mathrm{~s}, 1 \mathrm{H}), 7.18(\mathrm{~d}, J=9.2$ $\mathrm{Hz}, 1 \mathrm{H}), 7.11(\mathrm{~d}, J=8.0 \mathrm{~Hz}, 1 \mathrm{H}), 6.66(\mathrm{~s}, 1 \mathrm{H}), 6.22$ $6.24(\mathrm{~m}, 1 \mathrm{H})$ (figure $\mathrm{S} 1$ in Supplementary information). ${ }^{13} \mathrm{C}$ NMR (DMSO- $\left.d_{6}\right)$ 145.03, 143.50, 142.85, 140.77, 137.45, 127.33, 124.61, 122.18, 115.84, 110.61, 101.62 (figure S2 in Supplementary information). MS (ESIMS): $\mathrm{m} / \mathrm{z}$ calculated for $\mathrm{C}_{11} \mathrm{H}_{8} \mathrm{~N}_{6} \mathrm{O}_{3}, 272.07$, found: $[\mathrm{M}-1]^{+}, 270.9$. (figure $\mathrm{S} 3$ in Supplementary information).

\subsection{Preparation of solutions}

The stock solutions of each anion $(5 \mathrm{mM})$ of $\mathrm{S}^{2-}, \mathrm{HSO}_{3}^{-}$, $\mathrm{S}_{2} \mathrm{O}_{3}^{2-}, \mathrm{NO}_{2}^{-}, \mathrm{F}^{-}, \mathrm{Cl}^{-}, \mathrm{Br}^{-}, \mathrm{I}^{-}, \mathrm{CO}_{3}^{2-}, \mathrm{SO}_{4}^{2-}, \mathrm{OH}^{-}$,
$\mathrm{OAc}^{-}, \mathrm{SO}_{3}^{2-}, \mathrm{HCO}_{3}^{-}, \mathrm{HSO}_{4}^{-}, \mathrm{H}_{2} \mathrm{PO}_{4}^{-}, \mathrm{HPO}_{4}^{2-}, \mathrm{PO}_{4}^{3-}$, $\mathrm{CN}^{-}$were prepared in deionized water from their sodium or potassium salts. Stock solution of $\mathbf{1}(1 \mathrm{mM})$ was prepared in acetonitrile. PBS buffer solutions $(10 \mathrm{mM})$ were prepared by using proper amount of $\mathrm{NaH}_{2} \mathrm{PO}_{4}$ and $\mathrm{Na}_{2} \mathrm{HPO}_{4}$ under adjustment by a pH S-3C meter.

In titration experiments, $\mathbf{1}$ was diluted to a certain concentration $(30 \mu \mathrm{M}$ for absorption spectra and 10 $\mu \mathrm{M}$ for fluorescence spectra) with $\mathrm{CH}_{3} \mathrm{CN}$-PBS (10 $\mathrm{mM}, \mathrm{pH}=7.2,3: 1, \mathrm{v} / \mathrm{v})$. Then $3 \mathrm{~mL}$ of $1 \mathrm{CH}_{3} \mathrm{CN}-\mathrm{PBS}$ $(10 \mathrm{mM}, \mathrm{pH}=7.2,3: 1, \mathrm{v} / \mathrm{v})$ was put into a quartz optical cell with an optical path of $1 \mathrm{~cm}$. The stock solution of each anion was added into the quartz optical cell step by step via a microsyringe and the solution was stirred for $3 \mathrm{~min}$ before recording the spectra. For fluorescence measurements, excitation wavelength was set at $470 \mathrm{~nm}$ and emission was collected from $490 \mathrm{~nm}$ to $700 \mathrm{~nm}$. The bandwidth of excitation and emission slits were both set at $5 \mathrm{~nm}$. The quantum yields were measured using quinine sulfate in $1 \mathrm{~N} \mathrm{H}_{2} \mathrm{SO}_{4}(\phi=0.54)$ as reference with excitation at $350 \mathrm{~nm}^{39}$ using the following equation:

$$
\phi_{S}=\phi_{R} \frac{A_{R} F_{S} n_{S}^{2}}{A_{S} F_{R} n_{R}^{2}}
$$

where $\mathrm{A}$ and $\mathrm{F}$ are the absorbance and integrated fluorescence intensity, respectively, $n$ is the refractive index of the solvent, and $\mathrm{S}$ and $\mathrm{R}$ represent the sample and reference, respectively.

\section{Results and Discussion}

\subsection{Absorption properties}

The absorption responses of probe $\mathbf{1}$ to various anions including $\mathrm{S}^{2-}, \mathrm{HSO}_{3}^{-}, \mathrm{S}_{2} \mathrm{O}_{3}^{2-}, \mathrm{NO}_{2}^{-}, \mathrm{F}^{-}, \mathrm{Cl}^{-}, \mathrm{Br}^{-}$, $\mathrm{I}^{-}, \mathrm{CO}_{3}^{2-}, \mathrm{SO}_{4}^{2-}, \mathrm{OH}^{-}, \mathrm{OAc}^{-}, \mathrm{SO}_{3}^{2-}, \mathrm{HCO}_{3}^{-}, \mathrm{HSO}_{4}^{-}$, $\mathrm{H}_{2} \mathrm{PO}_{4}^{-}, \mathrm{HPO}_{4}^{2-}, \mathrm{PO}_{4}^{3-}, \mathrm{CN}^{-}$in $\mathrm{CH}_{3} \mathrm{CN}-\mathrm{PBS}(10 \mathrm{mM}$, $\mathrm{pH}=7.2,3: 1, \mathrm{v} / \mathrm{v})$ were explored. Compound $\mathbf{1}$ alone showed a maximum absorption peak at $496 \mathrm{~nm}$ in 


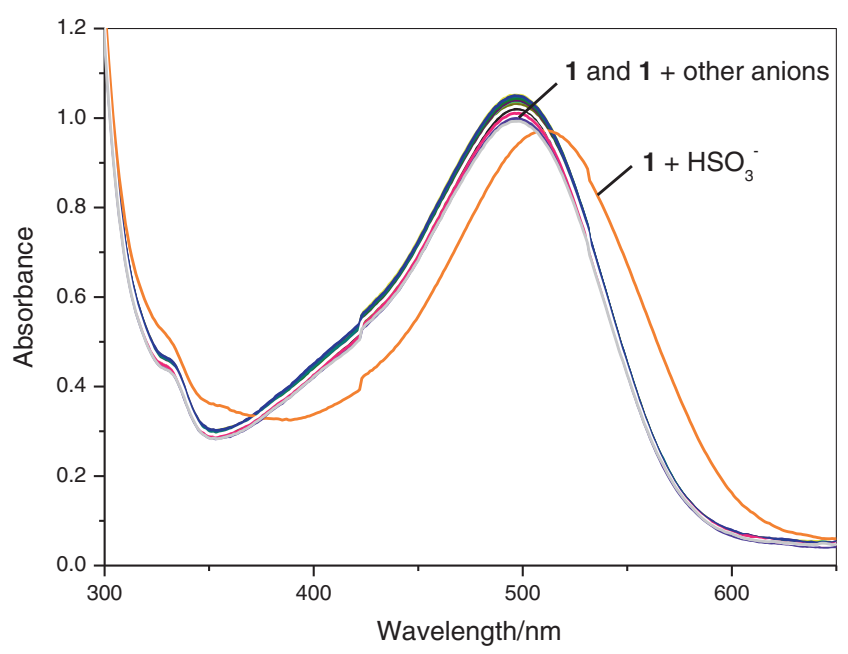

Figure 1. Absorption spectra of probe $1(30 \mu \mathrm{M})$ in the presence of various anions $(300 \mu \mathrm{M})$.

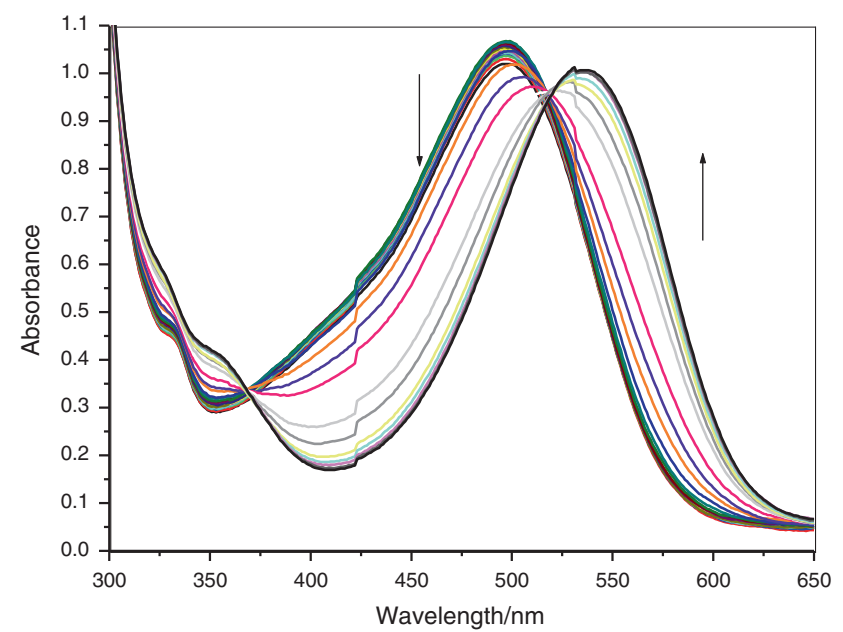

(a)

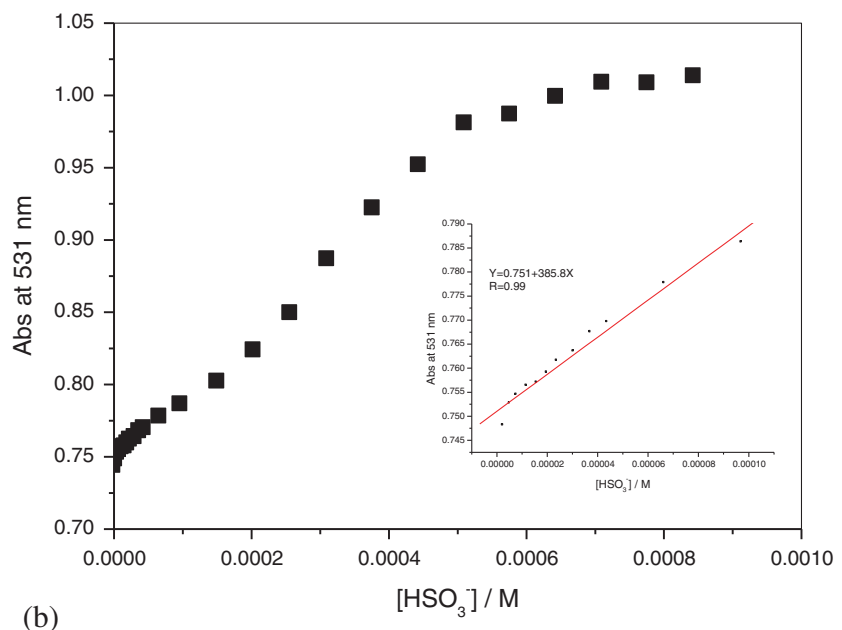

Figure 2. (a) Absorption spectra of $1(30 \mu \mathrm{M})$ in the presence of increasing concentrations of $\mathrm{NaHSO}_{3}$ in $\mathrm{CH}_{3} \mathrm{CN}$ PBS (10 mM, pH=7.2, 3:1, v/v). (b) Absorbance at $531 \mathrm{~nm}$ of 1 upon gradual addition of $\mathrm{HSO}_{3}^{-}$, inset: Absorbance at $531 \mathrm{~nm}$ of $1 \mathrm{vs} \mathrm{HSO}_{3}^{-}$in the concentration range of $0 \sim 120$ $\mu \mathrm{M}$.
$\mathrm{CH}_{3} \mathrm{CN}-\mathrm{PBS}(10 \mathrm{mM}, \mathrm{pH}=7.2,3: 1$, v/v). The peak at $496 \mathrm{~nm}$ could be assigned as its internal charge transfer (ICT) absorption transition. The absorption spectrum of probe 1 was bathochromically shifted in the presence of $\mathrm{HSO}_{3}^{-}$However, the absorption profiles of probe 1 remained unchanged upon addition of other anions (figure 1). Upon addition of $\mathrm{HSO}_{3}^{-}$, the absorbance at $496 \mathrm{~nm}$ decreased gradually and was red-shifted until a new absorption peak at $531 \mathrm{~nm}$ appeared and increased, indicating structural change upon interaction with bisulfite. Two isosbestic points at $368 \mathrm{~nm}$ and 516 $\mathrm{nm}$ appeared in the UV-vis spectra (figure 2a). The red solution of 1 in $\mathrm{CH}_{3} \mathrm{CN}-\mathrm{PBS}(10 \mathrm{mM}, \mathrm{pH}=7.2$, $3: 1, \mathrm{v} / \mathrm{v})$ turned to a purple-red color upon addition of $\mathrm{HSO}_{3}^{-}$. The absorbance at $531 \mathrm{~nm}$ increased linearly with the increasing of the $\mathrm{HSO}_{3}^{-}$concentration in the range of $2.7 \mu \mathrm{M} \sim 120 \mu \mathrm{M}$ (inset in figure $2 \mathrm{~b}$ ). Then, the absorbance increased only slightly with the increase of the concentration of $\mathrm{HSO}_{3}^{-}$(figure $2 \mathrm{~b}$ ). The relationship between the absorbance at $531 \mathrm{~nm}$ and $\mathrm{HSO}_{3}^{-}$concentration in the linear regime is: $A=385.8 C+0.751$, with a correlation coefficient of $\mathrm{R}=0.99$, where $C$ is the concentration of $\mathrm{HSO}_{3}^{-}$in $\mathrm{mol} / \mathrm{L}$. The detection limit, based on the definition by IUPAC was found to be 0.74 $\mu \mathrm{M}$ from 11 blank solutions.

\subsection{Fluorescence properties}

The fluorescence responses of $\mathbf{1}$ with different concentrations of $\mathrm{HSO}_{3}^{-}$in $\mathrm{CH}_{3} \mathrm{CN}-\mathrm{PBS}(10 \mathrm{mM}, \mathrm{pH}=7.2$, $3: 1, \mathrm{v} / \mathrm{v}$ ) were measured (figure $3 \mathrm{a}$ ). When excited at $470 \mathrm{~nm}, 1$ showed a very weak fluorescence band centered at $540 \mathrm{~nm}(\phi<0.001)$. The titration of $\mathrm{HSO}_{3}^{-}$to 1 demonstrated an obvious emission increase of the band with slight blue-shift to $537 \mathrm{~nm}$. When $450 \mu \mathrm{M}$ bisulfite was added, nearly 10-fold fluorescent enhancement was obtained $(\phi=0.237)$. The fluorescence intensity increased linearly with increasing of the $\mathrm{HSO}_{3}^{-}$concentration in the range of $0 \sim 300 \mu \mathrm{M}$ (figure 3b). The relationship between the fluorescence intensity at 537 $\mathrm{nm}$ and $\mathrm{HSO}_{3}^{-}$concentration was: $I=1.31 \times 10^{6} \mathrm{C}+$ 44.94, with a correlation coefficient of $\mathrm{R}=0.9965$, where $C$ is the concentration of $\mathrm{HSO}_{3}^{-}$in $\mathrm{M}$. The detection limit, based on the definition by IUPAC was found to be $50.6 \mathrm{nM}$ from 11 blank solutions. The fluorescent results indicated that compound $\mathbf{1}$ is suitable for use as a fluorescent probe for bisulfite

Job's plot analysis ${ }^{40}$ using fluorescence method with a total concentration of $40 \mu \mathrm{M}$ at $537 \mathrm{~nm}$ revealed a maximum at about 0.5 mole fraction (figure 4), indicating 1:1 binding stoichiometry of $\mathbf{1}$ and $\mathrm{HSO}_{3}^{-}$. The association constant ${ }^{41}$ was calculated to be $1016 \mathrm{M}^{1}$ by using a Benesi-Hildebrand plot according to the 


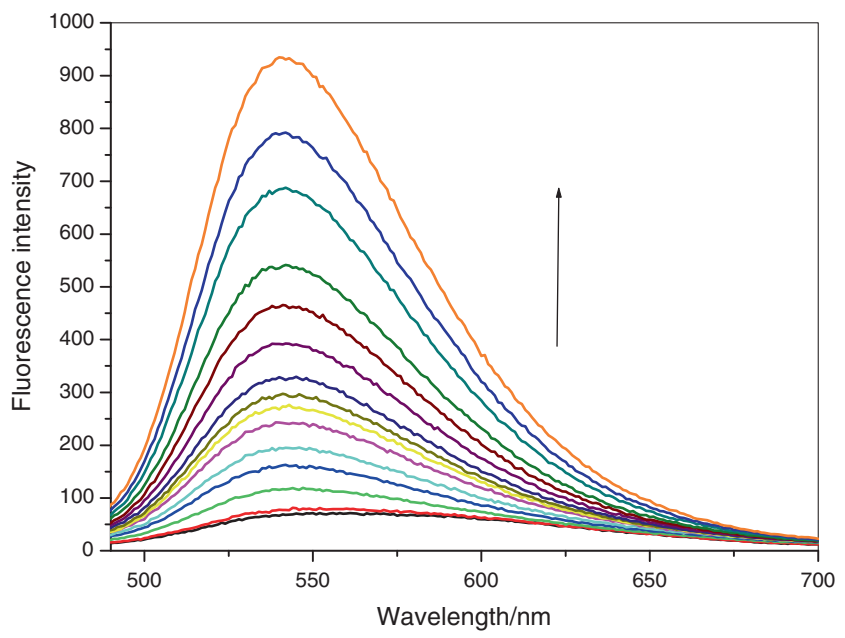

(a)

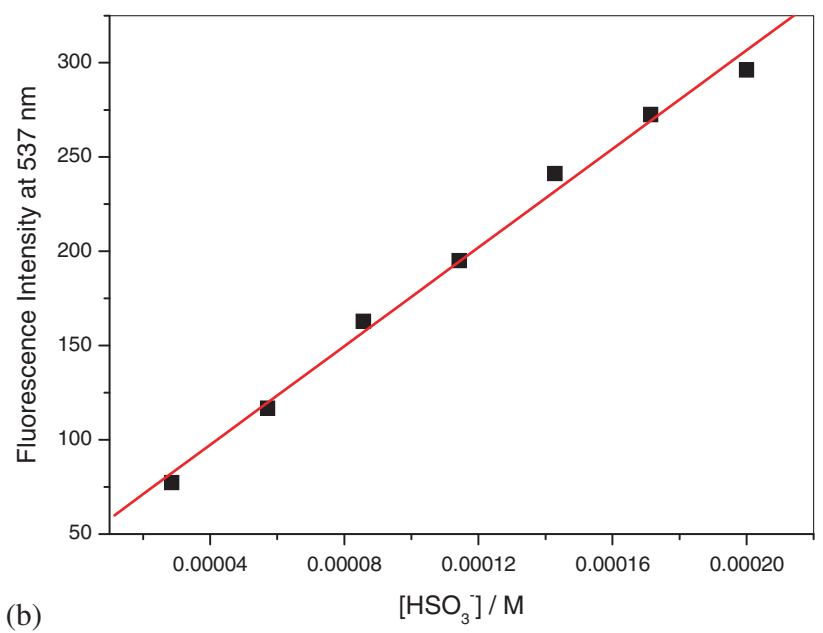

Figure 3. (a) Fluorescence spectra of of $1(10 \mu \mathrm{M})$ in the presence of increasing concentrations of $\mathrm{HSO}_{3}^{-}(0 \sim 57$ $\mu \mathrm{M})$ in $\mathrm{CH}_{3} \mathrm{CN}-\mathrm{PBS}(10 \mathrm{mM}, \mathrm{pH}=7.2,3: 1$, v/v). Excitation wavelength is $470 \mathrm{~nm}$. Bandwidth of both ex slit and em slit were set at $5 \mathrm{~nm}$. (b) Fluorescence intensity at $537 \mathrm{~nm}$ of $\mathbf{1}$ vs concentration of $\mathrm{HSO}_{3}^{-}$in the range of $29 \mu \mathrm{M} \sim 300 \mu \mathrm{M}$.

fluorescence titration profile (figure S4, Supplementary material).

After adding $400 \mu \mathrm{M}$ of anions, such as $\mathrm{S}^{2-}, \mathrm{HSO}_{3}^{-}$, $\mathrm{S}_{2} \mathrm{O}_{3}^{2-}, \mathrm{NO}_{2}^{-}, \mathrm{F}^{-}, \mathrm{Cl}^{-}, \mathrm{Br}^{-}, \mathrm{I}^{-}, \mathrm{CO}_{3}^{2-}, \mathrm{SO}_{4}^{2-}, \mathrm{OH}^{-}$, $\mathrm{OAc}^{-}, \mathrm{SO}_{3}^{2-}, \mathrm{HCO}_{3}^{-}, \mathrm{HSO}_{4}^{-}, \mathrm{H}_{2} \mathrm{PO}_{4}^{-}, \mathrm{HPO}_{4}^{2-}, \mathrm{PO}_{4}^{3-}$, $\mathrm{CN}^{-}$respectively to the $\mathrm{CH}_{3} \mathrm{CN}-\mathrm{PBS}(10 \mathrm{mM}, \mathrm{pH}=7.2$, $3: 1, \mathrm{v} / \mathrm{v})$ solution containing $10 \mu \mathrm{M}$ of 1 for $3 \mathrm{~min}$, only $\mathrm{HSO}_{3}^{-}$induced a significant fluorescence enhancement at $537 \mathrm{~nm}$ (figure 5). Other anions including $\mathrm{S}^{2-}, \mathrm{S}_{2} \mathrm{O}_{3}^{2-}, \mathrm{NO}_{2}^{-}, \mathrm{F}^{-}, \mathrm{Cl}^{-}, \mathrm{Br}^{-}, \mathrm{I}^{-}, \mathrm{CO}_{3}^{2-}, \mathrm{SO}_{4}^{2-}$, $\mathrm{OH}^{-}, \mathrm{OAc}^{-}, \mathrm{SO}_{3}^{2-}, \mathrm{HCO}_{3}^{-}, \mathrm{HSO}_{4}^{-}, \mathrm{H}_{2} \mathrm{PO}_{4}^{-}, \mathrm{HPO}_{4}^{2-}$, $\mathrm{PO}_{4}^{3-}, \mathrm{CN}^{-}$showed little changes in fluorescence spectra under the same conditions. The competition experiments indicated that less obvious fluorescent changes of probe 1 were observed in the presence of 40 equiv. of other anions. Upon further addition of 40 equiv. of

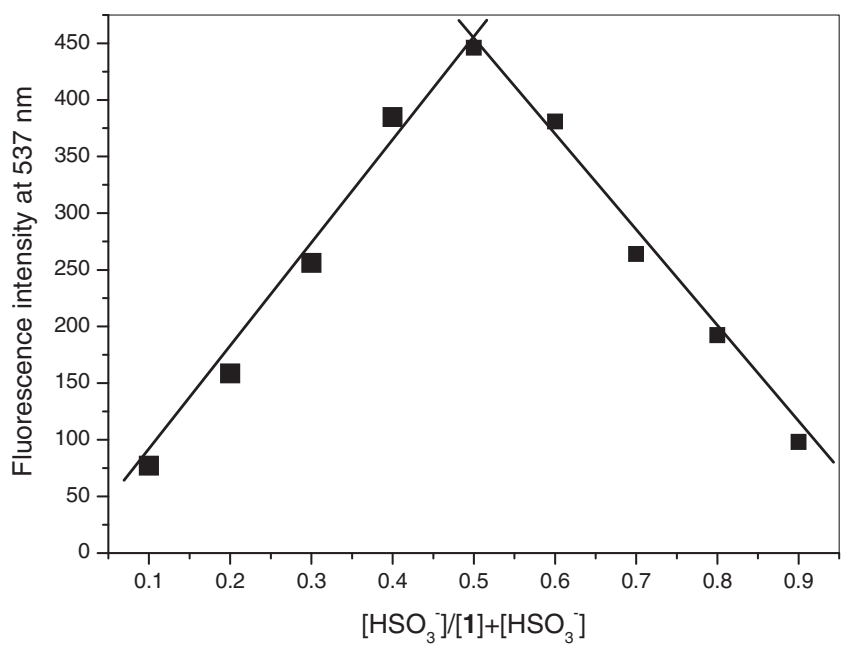

Figure 4. Job's plot for determining the stoichiometry of 1 and $\mathrm{HSO}_{3}^{-}$in $\mathrm{CH}_{3} \mathrm{CN}-\mathrm{PBS}(10 \mathrm{mM}, \mathrm{pH}=7.2,3: 1$, v/v) with a total concentration of $40 \mu \mathrm{M}$. Excitation wavelength is 470 $\mathrm{nm}$. Band width of ex slit and em slit were set at 5 and 10 $\mathrm{nm}$, respectively.

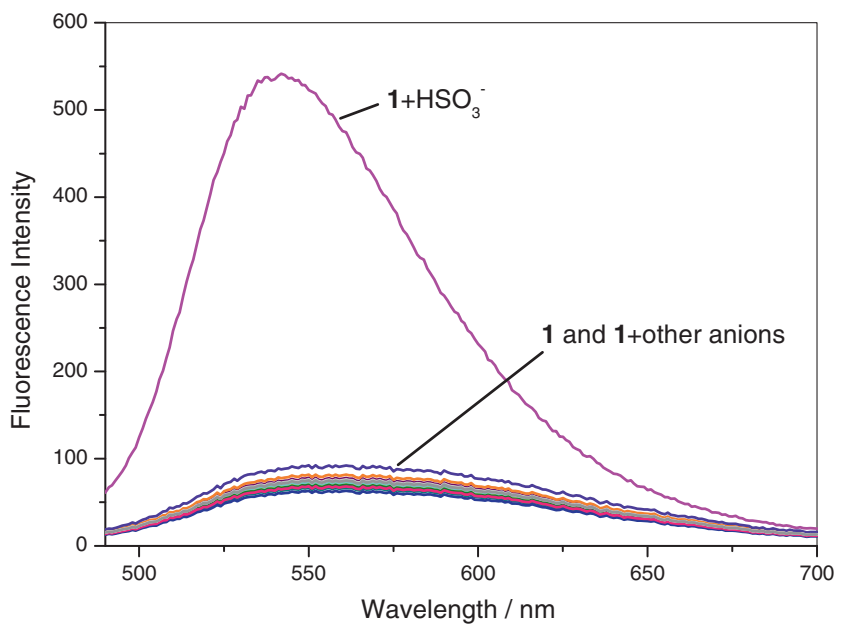

Figure 5. Fluorescence spectra of probe $1(10 \mu \mathrm{M})$ in the presence of various anions $(400 \mu \mathrm{M})$.

$\mathrm{HSO}_{3}^{-}$to the solution which containing probe $\mathbf{1}$ and 40 equiv. of competing anions, the change of the emission was similar to that as observed in the $1-\mathrm{HSO}_{3}^{-}$solution (figure 6). As a result, probe 1 displayed high selectivity to detect $\mathrm{HSO}_{3}^{-}$even in the presence of 40 equiv of other anions.

\subsection{Molecular calculations}

To understand the recognition process of $\mathbf{1}$ toward $\mathrm{HSO}_{3}^{-}, \mathrm{HOMO}$ and LUMO distributions of $\mathbf{1}$ and 1$\mathrm{HSO}_{3}^{-}$(assuming that $\mathrm{HSO}_{3}^{-}$was bound to $\mathbf{1}$ ) were determined by density functional theory (DFT) calculations at the B3LYP/6-31G* level using Gaussian 03 


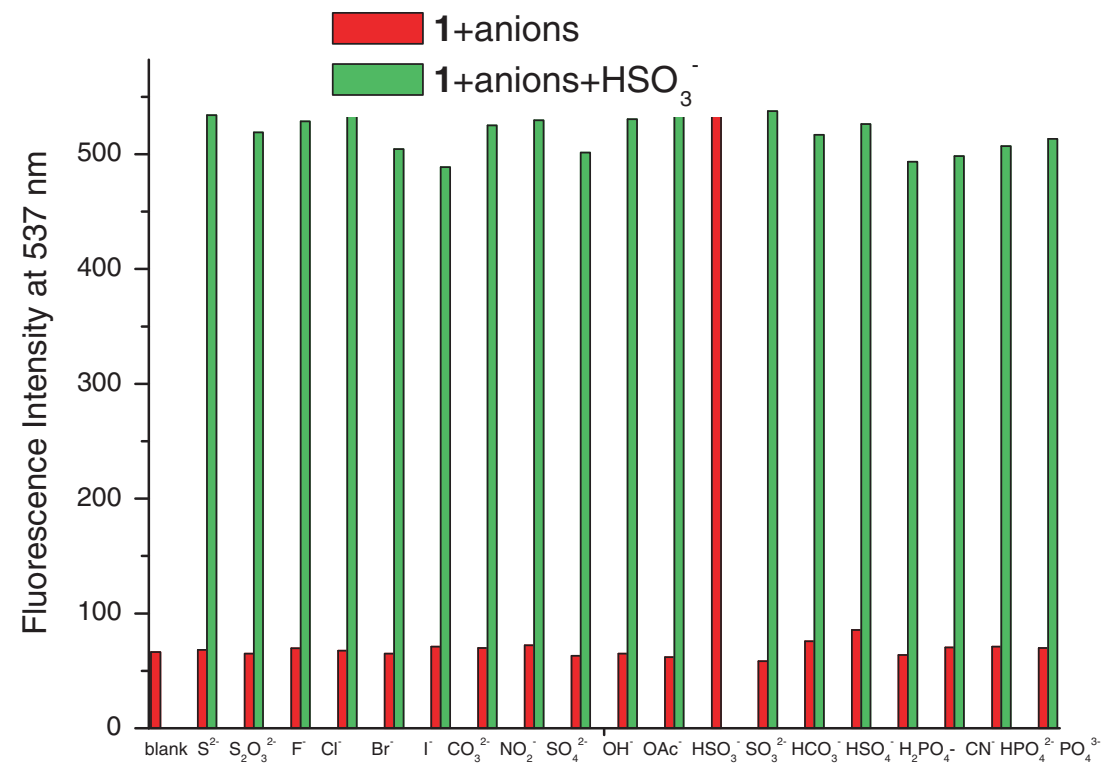

Figure 6. Selectivity of $\mathbf{1}(10 \mu \mathrm{M})$ for $\mathrm{HSO}_{3}^{-}$in the presence of other anions $(400 \mu \mathrm{M})$ in $\mathrm{CH}_{3} \mathrm{CN}-\mathrm{PBS}(10 \mathrm{mM}, \mathrm{pH}=7.2,3: 1$, v/v), red bars represent: blank, $\mathrm{S}^{2-}, \mathrm{S}_{2} \mathrm{O}_{3}^{2-}, \mathrm{F}^{-}, \mathrm{Cl}^{-}, \mathrm{Br}^{-}, \mathrm{I}^{-}, \mathrm{CO}_{3}^{2-}, \mathrm{NO}_{2}^{-}, \mathrm{SO}_{4}^{2-}, \mathrm{OH}^{-}, \mathrm{OAc}^{-}, \mathrm{HSO}_{3}^{-}$, $\mathrm{SO}_{3}^{2-}, \mathrm{HCO}_{3}^{-}, \mathrm{HSO}_{4}^{-}, \mathrm{H}_{2} \mathrm{PO}_{4}^{-}, \mathrm{HPO}_{4}^{2-}, \mathrm{PO}_{4}^{3-}, \mathrm{CN}^{-}$. Green bars represent the results for subsequent addition of $\mathrm{HSO}_{3}^{-}(400 \mu \mathrm{M})$ to the solution. Excitation wavelength is $470 \mathrm{~nm}$. Bandwidth of both ex slit and em slit were set at $5 \mathrm{~nm}$.

program. ${ }^{42}$ As shown in figure 7 , the NBD moiety, schiff base and pyrrole group of $\mathbf{1}$ were in the planar structure. The HOMO distribution of $\mathbf{1}$ was mainly

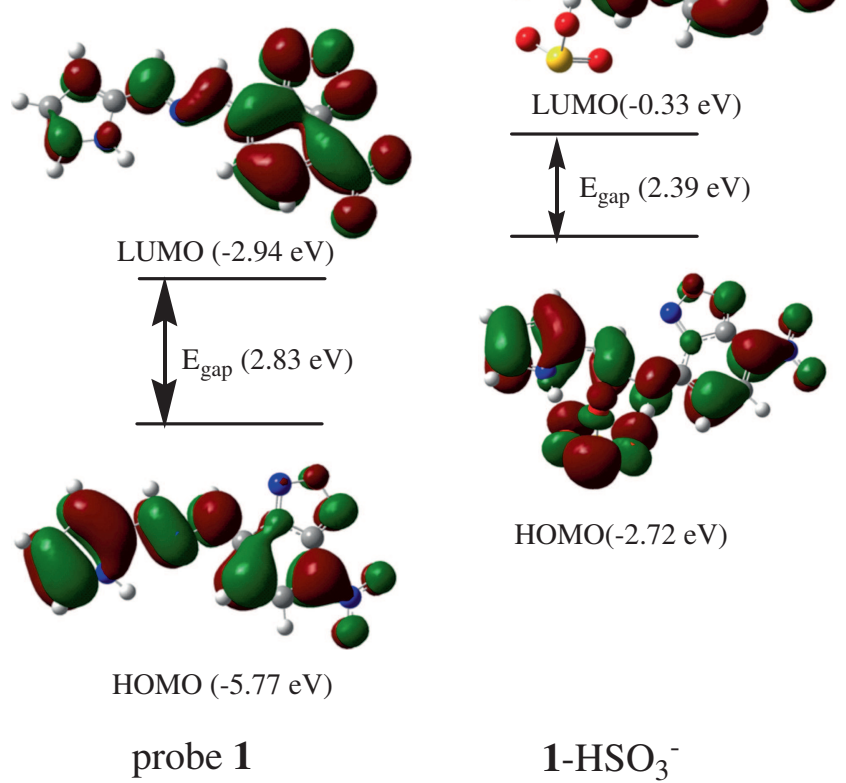

Figure 7. Calculated HOMO and LUMO distribution of probe $\mathbf{1}$ and its complex $\mathbf{1}-\mathrm{HSO}_{3}^{-}$. concentrated on the pyrrole group. The electron donor property of the pyrrole group was responsible for fluorescence quenching through PET effect (photoinduced electron transfer). Furthermore, the $\mathrm{C}=\mathrm{N}$ isomerization would also contribute to the nonfluorescent property of 1 It could be found that the NBD hydrazine moiety and the pyrrole group were trans to each other across the $\mathrm{C}=\mathrm{N}$ to keep its stable structure, after the formation of $1 \mathrm{HSO}_{3}^{-}$. Before the formation of $\mathbf{1}-\mathrm{HSO}_{3}^{-}$, the $\mathrm{N}-\mathrm{N}$ $\sigma$ bond in hydrazine could be free to rotate. After the addition of bisulfite, probe $\mathbf{1}$ had three sites for hydrogen bonding with the anion, one NH moiety on the NBD hydrazine one $\mathrm{NH}$ on pyrrole and one $\mathrm{N}$ atom in the schiff base to interact with the $\mathrm{H}$ atom of hydroxyl in $\mathrm{HSO}_{3}^{-}$(scheme 2). The calculated hydrogen bonding distances were $1.6204 \AA, 1.7634 \AA$ and $2.1757 \AA$ respectively. These hydrogen bonding interaction can restrict the free rotation of the N-N $\sigma$ bond in hydrazine and increase the structural rigidity of $\mathbf{1}$ The interaction with bisulfite caused a non-coplanar structure of probe 1 (The dihedral angle was changed from $0^{\circ}$ to $1.2787^{\circ}$ after its interaction with $\mathrm{HSO}_{3}^{-}$), which blocked the PET process and induced the enhancement of its fluorescence. Moreover, the energy gap between the $\mathrm{HOMO}$ and LUMO of $\mathbf{1}-\mathrm{HSO}_{3}^{-}$was smaller than that of probe 1 , in good agreement with the red shift of absorption spectra of probe 1 upon reaction with $\mathrm{HSO}_{3}^{-}$. The hydrogen bond-inhibited $\mathrm{C}=\mathrm{N}$ isomerization-reduced 


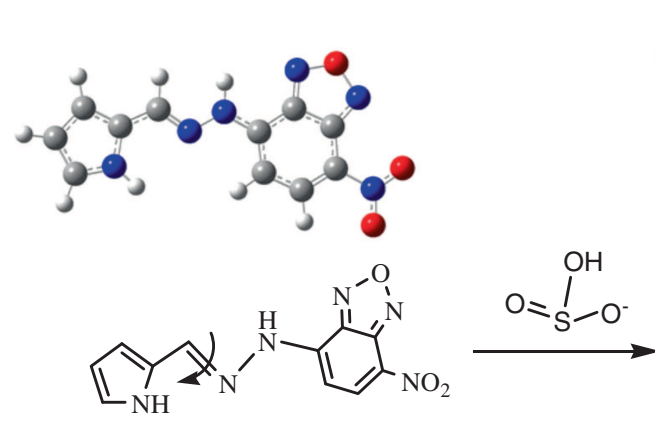

probe 1

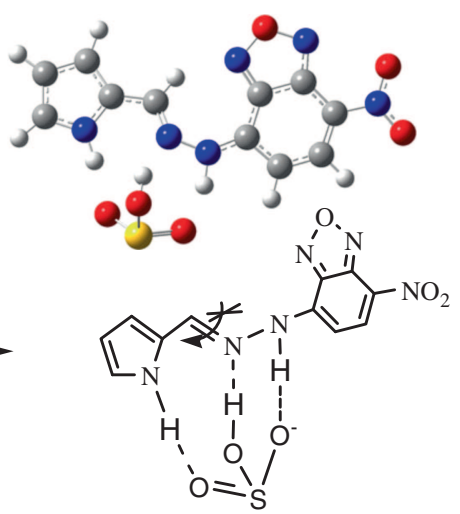

1- $\mathrm{HSO}_{3}{ }^{-}$

Scheme 2. Possible structure of 1:1 binding of probe $\mathbf{1}$ with bisulfite.

quenching mechanism ${ }^{43}$ could also be used to explain the interaction between probe $\mathbf{1}$ and $\mathrm{HSO}_{3}^{-}$. In this case, the NBD hydrazine moiety and the pyrrole group had to keep trans to each other across the $\mathrm{C}=\mathrm{N}$ for the formation of three hydrogen bonds with $\mathrm{HSO}_{3}^{-}$.

\subsection{MS analysis}

The data of ESI mass spectrum provided further evidence of the formation of a $1: 1$ 1- $\mathrm{HSO}_{3}^{-}$complex in

Table 1. Determination results for bisulfite in real samples ${ }^{a}$.

\begin{tabular}{llrcc}
\hline Sample & $\begin{array}{l}\text { Added } \\
(\mu \mathrm{M})\end{array}$ & $\begin{array}{c}\text { Found } \\
(\mu \mathrm{M})\end{array}$ & $\begin{array}{c}\text { Recovery } \\
(\%)\end{array}$ & $\begin{array}{c}\text { RSD } \\
(\%)\end{array}$ \\
\hline White wine & 0 & 6.2 & - & 3.1 \\
& 10 & 16.8 & 103.7 & 3.0 \\
& 50 & 55.9 & 99.3 & 2.8 \\
& 100 & 105.0 & 98.9 & 2.9 \\
Red wine & 0 & 13.7 & - & 2.8 \\
& 10 & 23.2 & 97.9 & 2.5 \\
& 50 & 63.1 & 99.1 & 2.7 \\
& 100 & 116.2 & 102.2 & 2.4 \\
Beer & 0 & 7.1 & - & 2.7 \\
& 10 & 17.7 & 103.5 & 3.1 \\
& 50 & 56.1 & 98.2 & 3.0 \\
& 100 & 109.0 & 101.8 & 2.8 \\
\hline
\end{tabular}

${ }^{a}$ Bisulfite concentrations were determined using a standard addition method ${ }^{43-45}$ by measuring increase of the fluorescence intensity of $\mathbf{1}$ at $537 \mathrm{~nm}$. The standard curve in figure S6 was used to extrapolate the unknown amount of bisulfite. Aliquots of the sample solution which was diluted 10-fold were added to $\mathrm{CH}_{3} \mathrm{CN}-\mathrm{PBS}(10 \mathrm{mM}, \mathrm{pH}=7.2,3: 1$, v/v) containing probe $1(5 \mu \mathrm{M})$, and the emission intensity at 537 $\mathrm{nm}$ was recorded, whereby the unknown concentrations of bisulfite were determined. For recovery studies, known concentrations of bisulfite were added to each sample and the total bisulfite concentration was determined following the method described above. Relative standard deviations were calculated on the basis of five measurements.
$\mathrm{CH}_{3} \mathrm{CN} / \mathrm{H}_{2} \mathrm{O}(3: 1, \mathrm{v} / \mathrm{v})$ solution (figure $\mathrm{S} 5$ in Supplementary information). The peak at $\mathrm{m} / \mathrm{z}=358.97$ (calcd. 359.02 ), corresponding to $\left[\mathbf{1}+\mathrm{HSO}_{3}-\mathrm{OH}+\mathrm{Na}\right]^{+}$, was observed when $\mathrm{HSO}_{3}^{-}(4 \mathrm{mM})$ is added to $1(0.1 \mathrm{mM})$, whereas free 1 exhibited a peak at $\mathrm{m} / \mathrm{z}=270.9$, which corresponds to $[\mathbf{1}-\mathrm{H}]^{+}$(figure S3 in Supplementary information). The MS data was considered to support the proposed recognition mechanism, indicating the two $\mathrm{NH}$ groups and $\mathrm{N}$ atom in $\mathrm{C}=\mathrm{N}$ as anion binding sites.

\subsection{Real sample analysis}

Probe 1 was used to examine the content of bisulfite in real life samples. White wine, red wine and beer bought from a supermarket were diluted 10 -fold with deionized water and analyzed by standard addition and recovery experiments. As shown in table 1, probe 1 was found to be suitable to determine the concentration of bisulfite with good recoveries in these samples. The bisulfite content in white wine, red wine and beer were 6.2, 13.7 and $7.1 \mu \mathrm{M}$, respectively.

\section{Conclusion}

A simple novel fluorescent probe based on NBD chromophore (probe 1) for turn-on and selective detection of bisulfite was developed. The absorption spectrum of probe 1 was bathochromically shifted and the fluorescence of $\mathbf{1}$ was greatly enhanced in the presence of $\mathrm{HSO}_{3}^{-}$. From the MS analysis and DFT calculations, two $\mathrm{NH}$ moieties and one $\mathrm{N}$ atom in $\mathrm{C}=\mathrm{N}$ of probe $\mathbf{1}$ were considered to interact with bisulfite through three hydrogen bondings. These hydrogen-bonding interactions would restrict the free rotation of the $\mathrm{N}-\mathrm{N} \sigma$ bond in hydrazine and increase the structural rigidity of $\mathbf{1}$, 
block the PET process and inhibit $\mathrm{C}=\mathrm{N}$ isomerization, resulting in significant fluorescent enhancement of $\mathbf{1}$.

\section{Supplementary Information}

All additional information about ${ }^{1} \mathrm{H}$ NMR (figure S1), ${ }^{13} \mathrm{C}$ NMR (figure S2), MS spectrum (figure S3) of compound 1, Benesi-Hildebrand plot (figure S4), MS spectrum of $1 \mathrm{HSO}_{3}^{-}$(figure S5) and the standard curve in figure S6 are given in the supplementary information. Supplementary information is available at www.ias.ac. in/chemsci.

\section{Acknowledgement}

This project was supported by the National Natural Science Foundation of China (NSFC, No.21102037).

\section{References}

1. Rostami A and Taylor M S 2012 Macromol. Rapid Commun. 3321

2. Kim S K, Kim H N, Zhu X, Lee H N, Soh J H, Swamy K M K and Yoon J 2007 Supramol. Chem. 19221

3. Kobayashi H, Ogawa M, Alford R, Choyke P L and Urano Y 2010 Chem. Rev. 1102620

4. Gale P A, Garcia-Garrido S E and Garric J 2008 Chem. Soc. Rev. 37151

5. Suksai C and Tuntulani T 2003 Chem. Soc. Rev. 32192

6. O'Neil E J and Smith B D 2006 Coord. Chem. Rev. 250 3068

7. Davis A P 2006 Coord. Chem. Rev. 2502939

8. Sessler J L, Camiolo S and Gale P A 2003 Coord. Chem. Rev. 24017

9. Bondy C R and Loeb S J 2003 Coord. Chem. Rev. 240 77

10. Choi K and Hamilton A D 2003 Coord. Chem. Rev. 240 101

11. Gale P A 2006 Acc. Chem. Res. 39465

12. Schmuck C 2006 Coord. Chem. Rev. 2503053

13. Schug K A and Lindner W 2005 Chem. Rev. 10567

14. Yoon J, Kim S K, Singh N J and Kim K S 2006 Chem. Soc. Rev. 35355

15. Best M D, Tobey S L and Anslyn E V 2003 Coord. Chem. Rev. 2403

16. Xu Z, Kim S K and Yoon J 2010 Chem. Soc. Rev. 39 1457

17. Llinares J M, Powell D and Bowman-James K 2003 Coord. Chem. Rev. 24057

18. Beer P D and Hayes E J 2003 Coord. Chem. Rev. 240 167

19. Steed J W 2009 Chem. Soc. Rev. 38506

20. Rice C R 2006 Coord. Chem. Rev. 2503190

21. Amendola V and Fabbrizzi L 2009 Chem. Commun. 5 513

22. Jun M E, Roy B and Ahn K H 2011 Chem. Commun. 47 7583

23. Peng X J, Wu Y K, Fan J L, Tian M Z and Han K L 2005 J. Org. Chem. 7010524
24. McFeeters R F 1998 J. Food Prot. 61885

25. Yang X, Guo X and Zhao Y 2002 Anal. Chim. Acta 456 121

26. Fazio T and Warner C R 1990 Food Addit. Contam. 7 433

27. Decnop-Weever L G and Kraak J C 1997 Anal. Chim. Acta 337125

28. Verma S K and Deb M K 2007 J. Agric. Food Chem. 55 8319

29. Huang Y M, Zhang C, Zhang X R and Zhang Z J 1999 Anal. Chim. Acta 39195

30. Bush R K, Taylor S L and Busse W J 1986 J. Allergy Clin. Immunol. 78191

31. Yang Y T, Huo F J, Zhang J J, Xie Z H, Chao J B, Yin C X, Tong H B, Liu D S, Jin S, Cheng F Q and Yan X X 2012 Sens. Actuators B 166665

32. Taylor S L, Higle N A and Bush R K 1986 Adv. Food Res. 301

33. Nichol G M, Parsons G H and Chung K F 1994 Br. J. Pharmacol. 111918

34. Reist M, Jenner P and Halliwell B 1998 FEBS Lett. 423 231

35. Lavis L D and Raines R T 2008 ACS Chem. Biol. 3142

36. Lakowicz J R 2006 In Principles of fluorescence spectroscopy. 3rd ed. (New York: Springer) p.15

37. Loura L M S, Fernandes F, Fernandes A C and Ramalho J P P 2008 BBA-Biomembranes 1778491

38. Key J A, Li C and Cairo C W 2012 Bioconjug. Chem. 23363

39. Birks J B 1970 In Photophysics of Aromatic Molecules (New York: Wiley-Interscience)

40. Connors K A 1987 In Binding Constants-The Measurement of Molecular Complex Stability (New York: John Wiley \& Sons)

41. Benesi H and Hildebrand J 1949 J. Am. Chem. Soc. 71 2703

42. Frisch M J, Trucks G W, Schlegel H B, Scuseria G E, Robb M A, Cheeseman J R, Montgomery J A, Vrevenjr T, Kudin K N, Burant J C, Millam J M, Iyengar S S, Tomasi J, Barone V, Mennucci B, Cossi M, Scalmani G, Rega N, Petersson G A, Nakatsuji H, Hada M, Ehara M, Toyota K, Fukuda R, Hasegawa J, Ishida M, Nakajima T, Honda Y, Kitao O, Nakai H, Klene M, Li X, Knox J E, Hratchian H P, Cross J B, Bakken V, Adamo C, Jaramillo J, Gomperts R, Stratmann R E, Yazyev O, Austin A J, Cammi R, Pomelli C, Ochterski W J, Ayala P Y, Morokuma K, Voth G A, Salvador P, Dannenberg J J, Zakrzewski V G, Dapprich S, Daniels A D, Strain M C, Farkas O, Malick D K, Rabuck A D, Raghavachari K, Fores-man J B, Ortiz J V, Cui Q, Baboul A G, Clifford S, Cioslowski J, Stefanov B B, Liu G, Liashenko A, Piskorz P, Komaromi I, Martin R L, Fox D J, Keith T, Al-Laham M A, Peng C Y, Nanayakkara A, Challacombe M, Gill P M W, Johnson B, Chen W, Wong M W, Gonzalez C and Pople J A 2003 Gaussian 03, revision B05, Wallingford, CT

43. Sun Y -Q, Wang P, Liu J, Zhang J and Guo W 2012 Analyst 1373430

44. Ros-lis J V, García B, Jiménez D, Martínez-Máñez R, Sancenón F, Soto J, Gonzalvo F and Valldecabres M C 2004 J. Am. Chem. Soc. 1264064

45. Liao W, Wu F, Wu Y and Wang X 2008 Microchim. Acta. 162147 